\title{
Tawazaun
}

Jurnal Pendidikan Islam

http://ejournal.uika-bogor.ac.id/index.php/TAWAZUN/index

Vol. 14, No. 1, 2021, e-ISSN: 2654-5845, hlm. 42-55, DOI: 10.32832/tawazun.v14i1.4009

\section{Konsep Pendidikan Adab dalam Kitab Al-Jâmi' Al-Ṣahîh Karya Imam Al-Tirmiżî dan Relevansinya dengan Tujuan Pendidikan Nasional}

\section{Haryanto}

Pesantren Ibnu Taimiyah Bogor, Indonesia

abufuad19@yahoo.co.id

\section{Abstract}

The character education program launched by the Government has not reaped encouraging results, as evidenced by the worsening moral decline that occurs in the midst of the nation's children, such as corruption, drug abuse, LGBT lifestyle, free sex association, fighting between students, students and villagers, intolerance among religious people, separatism that threatens the integrity of the Republic of Indonesia, and so forth. The concept of education in imam al-Tirmiziî's al-Jâmi' al-șahîh explains in detail the basic potential of man (heart, reason, taste, initiative and body), and explains the relationship between an individual and religious principles, with oneself and with his environment. The concept is very relevant to the purpose of national education, which is noble and morally praiseworthy to be able to improve the quality of individuals, families and communities to build a just and civilized national and state order, to further achieve the ideals of social justice for all Indonesians.

Keywords: Adab Education, Individual Quality, Justice

Abstrak

Program pendidikan karakter yang dicanangkan oleh Pemerintah belum menuai hasil yang menggembirakan, dibuktikan dengan semakin parahnya kemunduran moral yang terjadi di tengahtengah anak bangsa, seperti korupsi, penyalahgunaan obat-obat terlarang, gaya hidup LGBT, pergaulan seks bebas, tawuran antar pelajar, mahasiswa dan warga kampung, intoleransi antar umat beragama, separatisme yang mengancam keutuhan NKRI, dan lain sebagainya. Konsep pendidikan adab dalam kitab al-Jâmi' al-șahîh karya Imam al-Tirmižî menerangkan secara terperinci dalam mengembangkan potensi dasar manusia (hati, akal, rasa, karsa dan raga), serta menjelaskan relasi antara seorang individu dengan prinsip-prinsip agama, dengan diri sendiri dan dengan lingkungannya. Konsep sangat relevan dengan tujuan pendidikan nasional, yang mana adab mulia dan akhlak terpuji mampu meningkatkan kualitas individu, keluarga dan masyarakat untuk membangun tatanan berbangsa dan bernegara yang berkeadilan dan beradab, untuk selanjutnya mencapai cita-cita keadilan sosial bagi seluruh rakyat Indonesia.

Kata kunci: Pendidikan Adab, Kualitas Individu, Berkeadilan

\section{Pendahuluan}

Kegagalan pendidikan moral dan karakter yang digagas oleh Pemerintah ditandai dengan maraknya korupsi yang menyebabkan negara miskin, terbelit hutang yang berkepanjangan, daya beli masyarakat rendah, sehingga rakyat semakin sengsara. Korupsi cerminan gagalnya membangun peradaban dan karakter bangsa, produk dari sistem pembangunan mental yang buruk. Korupsi membuat bangsa tidak dapat berkompetisi secara global, karena tidak memiliki daya saing kompetitif. Korupsi merupakan karakter parasit yang akan membuat bangsa Indonesia hancur dengan lebih cepat. Menurut ICW, nilai korupsi 2017 sebesar 6,5 T dan suap sebesar 2,11 M (Tempo, 2018).

Article Information: Received January 5, 2021, Accepted April 30, 2021, Published May 6, 2021

Published by: Program Studi Magister Pendidikan Agama Islam Universitas Ibn Khaldun Bogor

How to cite: Haryanto, H. (2021). Konsep Pendidikan Adab Dalam Kitab Al-Jâmi’ Al-Ṣaḥị̂ Karya Imam Al-Tirmiżî Dan

Relevansinya Dengan Tujuan Pendidikan Nasional. Tawazun: Jurnal Pendidikan Islam, 14(1).

https://doi.org/10.32832/tawazun.v14i1.4009 
Sementara itu, KPAI mencatat bahwa kejahatan seksual yang banyak terjadi di dalam rumah tangga dan melibatkan anak-anak sebagai korbannya, mulai dari KDRT, pornografi, cybercrime, trafficking, hingga eksploitasi anak juga salah satu bukti rendahnya moral bangsa.

Permasalahan serius lainnya yang sangat memprihatinkan semua pihak adalah penegakan supremasi hukum, yang mana menurut The Word Justice Project (WJP) yang mengukur Indeks Negara Hukum (Rule of Law Index) tahun 2019 menempatkan Indonesia di rangking ke-62 dari 126 negara di dunia. Hal tersebut banyak disebabkan oleh faktor lemahnya penegakan hukum baik pidana maupun perdata, rendahnya civil justice, dan munculnya otoritarianisme baru yang diperankan oleh Pemerintah.

Pemerintah, melalui Pusat Analisis dan Sinkronisasi Kebijakan Sekjend (PASK) Kemendikbud pada 2017 menyingkap beberapa permasalahan yang dihadapi bangsa Indonesia dalam dunia pendidikan, juga berbagai persoalan yang mengancam keutuhan dan masa depan bangsa seperti maraknya tindakan intoleransi dan kekerasan atas nama agama yang mengancam kebinekaan dan keutuhan NKRI, munculnya gerakan-gerakan separatis, perilaku kekerasan dalam lingkungan pendidikan dan di masyarakat, kejahatan seksual, tawuran pelajar, pergaulan bebas dan kecenderungan anak-anak muda pada narkoba.

Melihat sekian banyak permasalahan di atas, apakah dapat dibenarkan tesis Lickona sebagaimana dinukil oleh Purnomo (2014:70-71) bahwa bangsa Indonesia sudah berada di jurang kehancuran? Lickona menyebut ada 10 kriteria kehancuran sebuah bangsa, yaitu: a) meningkatnya kekerasan di kalangan remaja, b) penggunaan bahasa dan kata-kata yang buruk, c) pengaruh peer group yang kuat dalam tindak kekerasan, d) meningkatnya perilaku merusak diri, seperti penggunaan narkoba, alkohol dan seks bebas, e) semakin kaburnya pedoman moral baik dan buruk, f) menurunnya etos kerja, g) semakin rendahnya rasa hormat kepada orang tua dan guru, h) rendahnya rasa tanggung jawab individu dan warga negara, i) membudayanya ketidakjujuran, dan j) adanya rasa saling curiga dan kebencian di antara sesama.

Purnomo juga menyimpulkan, paling tidak ada 4 faktor gagalnya pendidikan karakter di Indonesia, yaitu: Pertama, pembelajaran yang ada di sekolah kini cenderung memberikan porsi lebih untuk transfer of knowledge daripada transfer of value. Kedua, pembelajaran yang ada cenderung menitikberat-kan pada banyaknya hafalan. Ketiga, ada sebuah maqâlah yang menjelaskan bahwa sebuah metode lebih utama dari materi dan guru lebih utama dari sebuah metode serta ruh guru lebih utama dari segalanya. Hal inilah yang mungkin belum disadari dan tertanam pada diri guru. Keempat, keteladanan dari para guru merupakan hal mutlak yang tidak bisa ditawar-menawar.

Oleh karena itu, Pemerintah melalui Kemendikbud (2017:3) melakukan penataan ulang atau transformasi pendidikan nasional Indonesia tersebut dapat dimulai dengan menempatkan kembali karakter sebagai ruh atau dimensi terdalam pendidikan nasional berdampingan dengan intelektualitas yang tercermin dalam kompetensi. Dengan karakter yang kuat-tangguh beserta kompetensi yang tinggi yang dihasilkan oleh pendidikan yang baik, pelbagai kebutuhan, tantangan dan tuntutan baru dapat dipenuhi atau di atasi.

Menurut Farid dalam Education to the Method's of Sunnis (2011:11), secara umum pendidikan adalah upaya membentuk potensi-potensi individu peserta didik sesuai dengan nilai-nilai tertentu dan membantunya dalam memandang hakikat kehidupan secara benar, ia terkait dengan proses pengajaran yang mengeksplorasi segenap kemampuan mereka, lalu menumbuh kembangkannya, hingga mereka mampu berperan dalam berbagai bidang kehidupan.

Sejatinya pendidikan merupakan upaya setiap manusia untuk meningkatkan kualitas dirinya agar menjadi manusia seutuhnya, baik dalam ruang lingkup sebagai salah satu 
komponen masyarakat (eksistensi hablum minan naas), terlebih lagi dalam ruang lingkup sebagai seorang hamba Allah (eksistensi hablum minallab). Apabila umat Islam menyadari akan hal ini dan mewujudkannya, niscaya mereka akan menjadi pemimpin peradaban yang tinggi nan mulia. Akan tetapi tipu daya dan propaganda westernisasi dan liberalisasi global telah mengikis jati diri dan karakteristiknya, yakni karakter sebagai umat pembelajar yang selalu terus menerus bergerak di atas ilmu pengetahuan (Qs. Ali Imran: 79).

\section{Konsep Pendidikan Adab dalam Kitab al-Jâmi’ al-Ṣaḥị̂}

\section{A. Pengertian Adab}

Kitab al-Jâmi' al-Sahị̂h memuat satu pembahasan khusus tentang adab di jilid 2, dengan judul Kitab al-Âdâb 'an Rasûlillâh Șalallâhu 'Alaibi Wa Sallam. Kitab al-Âdâb ini berisi 123 ḥadî̀; mulai dari ḥadîs no. 2736 hingga 2858, terbagi menjadi 75 bab. Hadîs-ḥadîs dalam kitab ini berkisar tentang adab-adab pergaulan (al-Ádâb al-Ijtimâizyyah), seperti: adab bersin dan menguap, adab duduk dalam majlis, adab memelihara sunan fithrah, adab tidur, adab menaiki hewan tunggangan, adab menjaga pandangan, adab pergaulan laki-laki dan perempuan, adab menjaga aurat, adab berpakaian, adab pergaulan terhadap anggota keluarga dan adab berbicara.

Dalam kitab al-Jâmi' al-Ṣậḥ, adab dimaknai dengan ḥusnu al-khuluq (akhlak mulia) dan al-birr (kebajikan). Sebagaimana yang dijelaskan oleh Ibnu al-Mubarak saat ia menyifati akhlak mulia dengan mengatakan:

$$
\text { " هُوَ بَسْطُ الََْجْهِ وَبَنْلُ الَهَعْرُوفِ وَكَنُّ الأَذَى ". }
$$

(Akhlak yang mulia itu) adalah wajah yang ceria, mengerjakan kebaikan, dan mencegah keburukan.

(HR. al-Tirmiżî: 2I36)

Sedangkan ḥadîs Nabi yang menjelaskan tentang al-birr (kebajikan) sebagai akhlak yang mulia adalah saat beliau Salallâhu 'Alaibi Wa Sallam ditanya tentang al-birr tersebut, beliau menjawab:

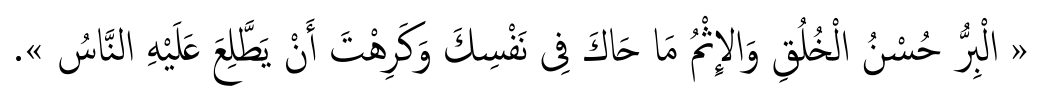

"Al-Birr (kebajikan) adalah akhlak yang mulia, sedangkan dosa adalah yang menggelisahkan jiwamu dan engkau tidak ingin diketahui oleh manusia." (HR. al-Tirmidzi: 2565)

Demikian pula yang dijelaskan oleh al-Mubârakfûri (2005, 3:183) yang mensyarah al-Jâmi' al-Ṣậh ketika menerangkan ḥadî̀ tentang mendidik seorang hamba sahaya (ḥadî̀ No. 1116, al-Jâmi' al-Tirmiž̀i), bahwa yang dimaksud dengan adab adalah busnu al-khuluq.

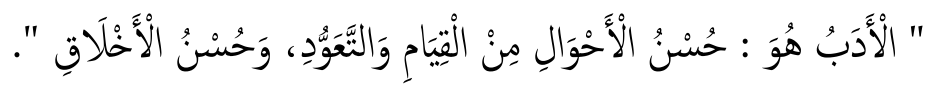

Adab adalah baiknya keadaan dalam penunaian kewajiban dan kebiasaan, dan baiknya akhlak (akhlak mulia).

Dari beberapa keterangan di atas, adab dimaknai dengan akhlak mulia atau perilaku yang baik dalam perkataan (aqwâl) dan perbuatan (afẩ). Hal ini menunjukkan bahwa pengertian adab lebih banyak ditinjau dari aspek tataran operasional (aplikatif), karena yang diinginkan dari adab dan akhlak mulia adalah efek positif (kebaikan) yang dapat dirasakan dan bermanfaat bagi diri sendiri dan orang lain.

Kitab al-jâmi' al-Ṣahih memuat dua hadits yang secara spesifik menyebutkan istilah alta'dîh, dengan bentuk fi'il (kata kerja) dan dengan bentuk mașdar (kata benda). Pertama, 


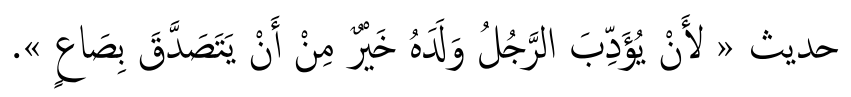

"Seseorang mendidik anaknya dengan adab yang baik itu lebih baik baginya dari bersedekah dengan satu sha.” (HR. al-Tirmiżî̀: I95I)

Kedua,

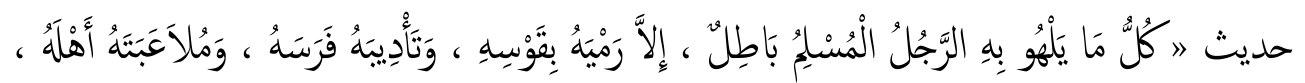

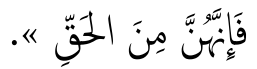

"Semua yang dilakukan seorang muslim untuk bersenda gurau adalah bațil (sia-sia) kecuali memanah, melatih kudanya dan mencumbu istrinya. Semuanya itu adalah hak (sah, benar adanyapen).” (HR. al-Tirmiżîi: I637)

Sedangkan untuk lafą adab itu sendiri, disebutkan dalam satu ḥadîs, yaitu:

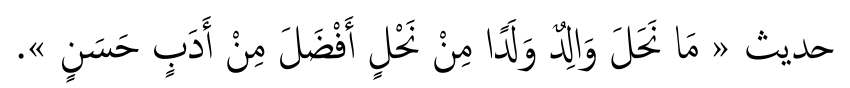

"Tidaklah seorang bapak memberikan sesuatu kepada anaknya yang lebih utama daripada mengajarkan adab yang baik.” (HR. al-Tirmiżî̀: 1952)

Terkait dengan ḥadìs terakhir yang tercantum di atas, al-Mubârakfûri (2005, 5:183) mengatakan, karena adab yang baik dapat mengangkat seorang hamba menjadi raja.

Dari keterangan-keterangan tersebut di atas, penulis menarik simpulan bahwa pengertian adâb dalam kitab al-Jâmi' al-Șaḥ̣̂ adalah sekumpulan akhlak-akhlak mulia dalam perkataan dan perbuatan, yang tampak maupun yang tersembunyi. Sedangkan al-ta'dî́b dipahami sebagai proses pendidikan, pelatihan dan pengajaran, serta pembiasaan perilaku dan budi pekerti yang terpuji, namun tidak menutup kemungkinan untuk sesekali adanya pemberian sanksi (pembinaan) atas pelanggaran yang terjadi dengan kesengajaan.

\section{B. Landasan Pendidikan Adab}

Secara umum konsep pendidikan adab (akhlak) atau karakter dalam agama Islam dibangun di atas prinsip-prinsip keimanan. Menurut al-Mubârakfûri (2005, 3:241), bahwa kesempurnaan iman mewajibkan (mengharuskan) kebaikan akhlak (akhlak mulia) dan berbuat ihsan (baik) kepada seluruh umat manusia.

Ayat-ayat al-Qur'an yang menerangkan hal ini sangat banyak, begitu pula dengan hadîś-

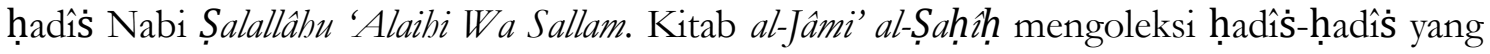
menjelaskan korelasi adab (akhlak) dengan keimanan di beberapa tempat, diantaranya:

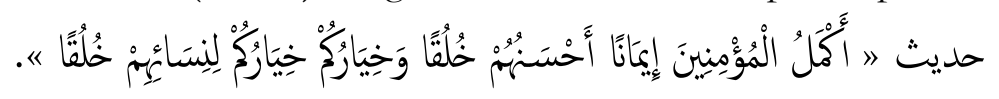

"Di antara orang-orang beriman yang paling sempurna keimanannya adalah yang paling baik akblaknya, dan sebaik-baik kalian adalah yang paling baik akblaknya kepada istri-istrinya." (HR. alTirmiżî: 1195)

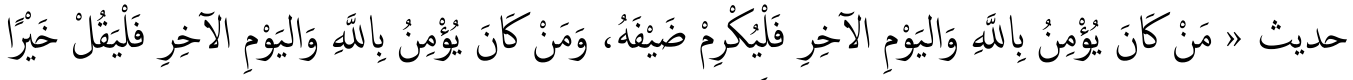

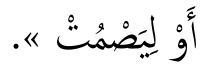

"Siapa yang beriman kepada Allah dan Hari Akhir hendaknya ia memuliakan tamunya, dan siapa yang beriman kepada Allah dan Hari Akhir hendaknya ia berkata yang baik atau diam." (HR. alTirmiżî̀: 2500) 


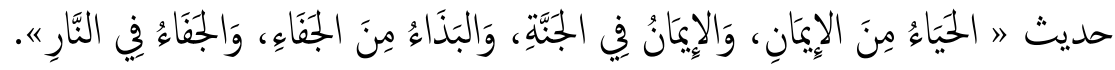

"Malu termasuk bagian dari keimanan, dan keimanan itu di dalam surga, sedangkan perkataan keji merupakan bentuk kekerasan, dan kekerasan itu di dalam neraka.” (HR. al-Tirmiżî̀: 2009)

Hadîs -ḥadîs tersebut menerangkan dengan gamblang bahwasanya adab-adab dan akhlakakhlak mulia disebutkan beriringan dengan nilai-nilai keimanan, iman kepada Allah Subbânahu $W a$ Ta'ala dan iman kepada negeri akhirat. Dialah sebagai pendorong dan penggerak utama dari semua perilaku terpuji dan akhlak mulia. Tanpa iman yang kuat menancap dalam diri seorang hamba, akan sulit dan berat baginya untuk menjalankan semua perintah-perintah Allah, maupun untuk meninggalkan dan menjauhi larangan-larangan Allah.

Ibnu Mas'ud Radiyallâbu 'Anhu (dalam al-'Abbad, 2018, 2:462) pernah mengatakan:

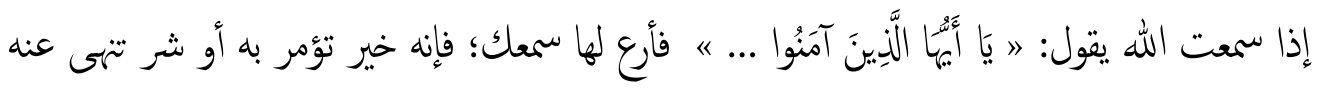

Jika kamu mendengar Allah Subhânahu Wa Ta’ala berfirman: "Hai orang-orang yang beriman...", maka siapkan pendengaranmu baik-baik; karena setelahnya akan ada kebaikan yang diperintahkan (untuk mengerjakannya) atau akan ada kejelekan yang dilarang (untuk menjauhkannya).

Menurut al-Qatțan (2000: 50) dalam Mabâhis fì 'Ulûm al-Qur'ân, disebutkan bahwa ayatayat al-Qur'an yang dimulai dengan yâ ayyubâ al-laìina âmanû adalah ayat-ayat madaniyah yang berisi hukum-hukum agama, baik berupa perintah maupun larangan. Tidak kurang dari 89 kali penyebutan yâ ayyuhâ al-lazîna âmanû dalam al-Qur'an. Hal ini menegaskan bahwa penunaian syari'at agama Islam lebih ditujukan kepada kaum muslimin yang telah tertanam dan tertancap nilai keimanan itu dengan kokoh.

\section{Tujuan Pendidikan Adab}

Dalam konsepsi Agama Islam, tujuan akhir dari seluruh aktivitas manusia -termasuk pendidikan- adalah memperoleh kebahagiaan di akhirat, baik berupa pahala yang besar dan berlipat ganda, timbangan kebaikan yang berat, tingginya derajat dan dihapuskannya dosa, hingga dimasukkan ke dalam surga dan dijauhkan dari api neraka. Oleh karena itu ayat-ayat al-Qur'an dan ḥadî̀s-ḥadîs Nabi Șalallâhu 'Alaibi Wa Sallam selalu mengingatkan manusia akan tujuan akhir tersebut dan menganjurkannya untuk berupaya secara maksimal mencapainya.

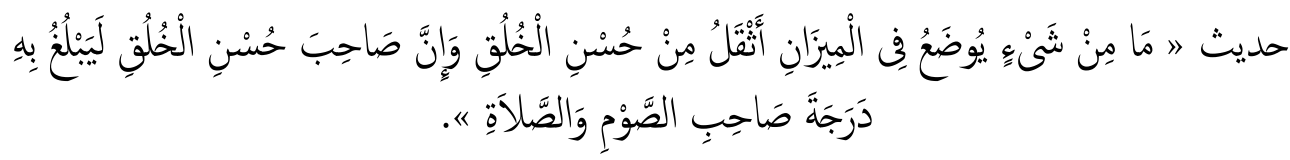

"Tidak ada sesuatu yang diletakkan dalam timbangan amal lebih berat dari akhlak yang baik, dan orang yang berakhlak mulia benar-benar mencapai derajat orang yang berpuasa dan mendirikan shalat." (HR. al-Tirmiżî̀: 2I34)

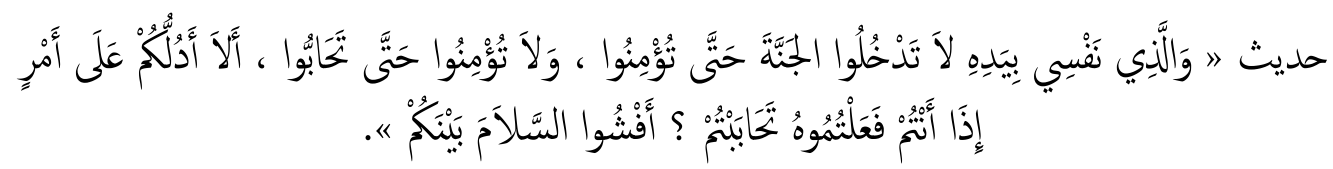

"Demi Żat yang jiwaku berada di Tangan-Nya, kalian semua tidak akan masuk surga hingga kalian semua beriman, dan kalian tidak akan mencapai kesempurnaan iman hingga kalian saling mencintai. Maukah aku tunjukkan kepada kalian sesuatu urusan yang jika kalian lakukan niscaya kalian akan saling mencintai? Tebarkanlah salam di antara kalian.” (HR. al-Tirmiżî̀: 2688). 
Hadîś-ḥadîs tersebut menerangkan serangkaian akhlak-akhlak terpuji dan adab-adab mulia, seperti: adab mengucapkan salam, berlaku jujur, tidak berdusta, membantu sesama kaum muslimin, meringankan beban orang-orang yang kesusahan, adab menuntut ilmu dan lain sebagainya, semuanya disebutkan beriringan dengan keimanan kepada segala hal yang mendatangkan kebahagiaan di negeri akhirat, berupa diangkat derajatnya yang tinggi, dihapuskannya dosa dan kesalahan, diletakkan dalam timbangan kebaikan di akhirat, dibangunkan untuknya rumah istana di surga, para malaikat memberikan penghormatan kepadanya, dan lain sebagainya. Semuanya itu merupakan cita-cita, keinginan dan puncak tujuan seorang muslim dalam menjalankan kehidupan di dunia ini.

Maka sejatinya, seluruh rangkaian program dan kurikulum pendidikan diarahkan untuk mewujudkan manusia yang berbahagia di dunia dan di akhirat. Kebahagiaan yang hakiki, yang berasal dari kebahagiaan hati dan jiwa. Sementara hati dan jiwa itu sendiri berada dalam genggaman Al-Rahman Subbânahu $W a$ Ta'ala. Di dalam hati dan jiwa itulah tertanam keimanan dan ketakwaan.

\section{Kurikulum Pendidikan Adab}

Secara konseptual pendidikan Islam bertujuan membentuk muslim yang seutuhnya, mengembangkan seluruh potensi manusia, baik yang berbentuk jasmaniah maupun rohaniah, menumbuhsuburkan hubungan yang harmonis setiap pribadi dengan Allah, manusia dan alam semesta (Ma'arif, 2007:45).

Dalam hal ini, kitab al-Jâmi' al-Șaḥ̣̂̂ karya Imam al-Tirmiżi memuat sebuah ḥadî̀ dari Nabi Șalallâbu 'Alaibi Wa Sallam, yaitu:

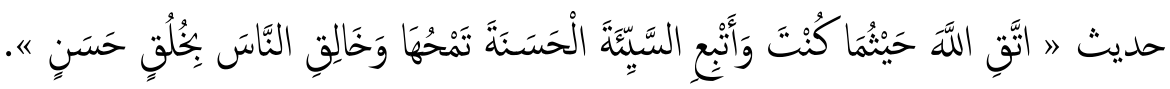

"Bertakwalah kepada Allah di mana saja kamu berada, iringilah kejelekan dengan kebaikan niscaya ia akan menghapuskannya, dan pergaulilah manusia dengan akhlak yang baik." (HR. al-Tirmidzi: 2II5)

Menurut Ibnu Ḥajar al-Haitâmi (2008: 150), ḥadî̉ ini mengumpulkan seluruh hukumhukum syariat, lantaran syariat Islam itu tidak lepas dari perintah dan larangan, itulah agama Islam, karena ia mencakup apa yang terdapat dalam hadî̀ Jibril 'Alaibi al-Salâm yang terdiri prinsip-prinsip keimanan, keislaman dan ihsan."

Al-Munâwî (1994, 1:115) berpendapat, bahwa ḥadî̀ ini termasuk ke dalam kaidah-kaidah penting, karena ia menjelaskan jalan kebaikan di dunia dan di akhirat, ia mencakup apa yang menjadi kewajiban seorang hamba untuk memperhatikan hak Sang Pencipta dan hak makhluk. Sebagian ulama mengatakan: Ia mencakup seluruh hukum-hukum syariat karena semuanya disebutkan di dalamnya. Pendapat lain mengatakan: Hadîs itu memperinci segala sesuatu dengan baik, mencakup tiga ruang lingkup hukum, masing-masingnya terdapat pembahasan yang luas dan saling terkait satu dengan yang lainnya."

Menurut al-Katîrî (2016), ḥadîs ini menjelaskan hak Allah Subhânahu Wa Ta'ala, hak diri sendiri dan hak manusia, ia meletakkan dasar-dasar pencegahan, kriteria kebaikan, penyelesaian masalah. Hadî̀ ini menyebutkan tentang metode seorang muslim dalam berinteraksi dengan Rabbnya dan dengan sesama manusia. Maka interaksi dengan Rabbnya melalui pelaksanaan prinsip-prinsip takwa, dan interaksi dengan manusia melalui pergaulan akhlak yang mulia, jika ia mengurangi kadarnya dalam dua keadaan tersebut, maka ia harus memperbaiki kesalahannya itu dengan cara bertobat dan mengerjakan perbuatan yang baik.

Kitab al-Jâmi' al-Ṣaḥ̂h karya Imam al-Tirmiżi menyebutkan beberapa adab terpenting yang berkaitan dengan tiga interaksi tersebut, yang oleh penulis dimasukkan ke dalam ruang 
lingkup pendidikan adab, yaitu: Pertama, adab terhadap prinsip-prinsip agama, disebut juga dengan al-ÂAab al-Syar'iyyah, sebagaimana tercantum dalam hadits Jibril 'Alaihi al-Salâm, yaitu rangkaian rukun-rukun Islam, Iman dan Ihsan. Dalam hal ini penulis membatasinya ke dalam empat relasi, yaitu: a) Adab kepada Allah Subhânahu Wa Ta'ala. b) Adab kepada Rasûlullâh Șalallâbu 'Alaibi Wa Sallam. c) Adab kepada al-Qur'ân al-Karîm. d) Adab kepada sunnah Nabi Salallâbu 'Alaibi Wa Sallam.

Kedua, adab kepada diri sendiri, disebut juga dengan al-Âdâb al-Fardiyah, meliputi pemeliharaan al-Darûriyât al-Khams, yaitu: a) Adab memelihara (menjaga) agama secara totalitas, baik dalam aspek akidah, ibadah maupun mu'amalah dan akhlak. b) Adab memelihara (menjaga) keselamatan jiwa dan eksistensi manusia secara lahir dan bațin. c) Adab memelihara (menjaga) kesehatan dan kebaikan akal, baik fisiknya maupun fungsinya. d) Adab memelihara (menjaga) kehormatan diri, dalam hal ini yang dimaksud adalah kejelasan dan kebersihan silsilah nasab (keturunan) secara keseluruhan. e) Adab memelihara (menjaga) harta benda sehingga mendatangkan keberkahan, dengan melihat sumber pendapatannya dan sarana penyalurannya. f) Adab menjaga sunan al-fițrah.

Ketiga, adab kepada orang lain, disebut juga adab pergaulan (al-Âdâb al-Ijtimẩizyah), yang meliputi: a) Adab kepada anggota keluarga, yakni; orang tua, anak, istri, dan kerabat. b) Adab kepada masyarakat sekitar, yakni; tetangga, anak-anak yatim, janda-janda jompo, orang-orang miskin, dan kaum muslimin umumnya. c) Adab pergaulan lainnya, seperti: adab menuntut ilmu, adab majlis, adab interaksi antara pemimpin dengan yang dipimpin dan adab penegakan hukum.

\section{Metode Pendidikan Adab}

Kitab al-Jâmi' al-Sahịh karya Imam al-Tirmidzi mencantumkan hadî̀'hadîs tentang metode pembelajaran yang beraneka ragam, baik metode itu dilakukan langsung oleh Rasûlullâh Șalallâhu 'Alaibi Wa Sallam maupun yang dipahami oleh para șahâbat, baik disebutkan secara jelas maupun menurut isyarat yang terdapat di dalam ḥadîs itu sendiri. Metode-metode itu diantaranya adalah:

\section{Pengajaran (al-Ta'lîm).}

Pengajaran merupakan metode yang paling umum dilakukan untuk menyampaikan informasi pengetahuan, ataupun untuk memberikan pengarahan dan motivasi, baik pengajaran berupa teori maupun praktik. Proses al-ta'lim dilakukan secara berulang dan terus menerus hingga mampu memberikan efek (pengaruh) positif pada diri peserta didik (alHâazimî, 2015: 93).

Dalam hal ini ada contoh pengajaran sebuah doa yang dibaca ketika seseorang hendak tidur, yaitu hadîs yang menyebutkan bahwa ada seseorang termasuk Banî Hanzalah berkata: Aku menemani Syaddâd bin Aus Radiyallâbu 'Anbu dalam suatu perjalanan, lalu ia berkata: Ketahuilah, aku akan ajarkan kepadamu apa yang diajarkan Rasûlullâh Șalallâhu 'Alaihi Wa Sallam kepada kami, agar kami selalu membaca doa:

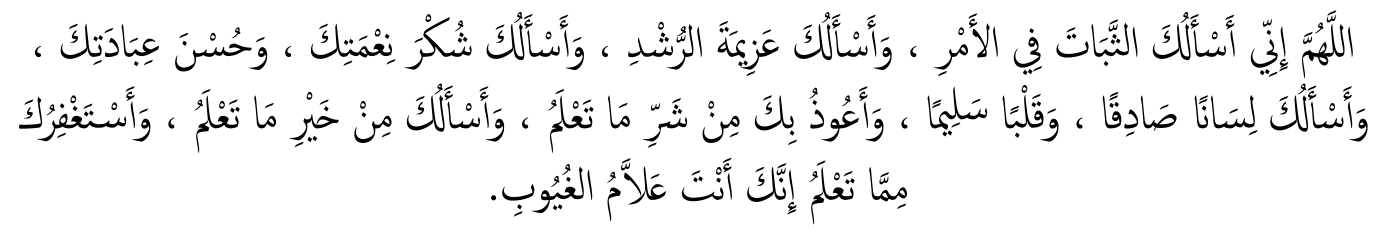

"Ya Allah, aku memohon kepada-Mu keteguhan hati dalam urusan ini (agama Islam), aku memohon kepada-Mu kekuatan petunjuk, aku memohon kepada-Mu untuk mensyukuri nikmat$\mathrm{Mu}$ dan memperbagus ibadahku kepada-Mu. Aku memohon kepada-Mu ucapan yang jujur dan hati yang bersih. Aku berlindung kepada-Mu dari keburukan yang Engkau ketahui dan memohon 
kepada-Mu dari kebaikan yang Engkau ketahui. Aku memohon ampunan kepada-Mu dari dosa yang Engkau ketahui, karena sesungguhnya Engkau maha mengetahui perkara-perkara gaib.” (HR. al-Tirmiżî: 3407).

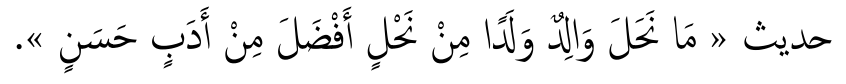

"Tidaklah seorang bapak mengajarkan sesuatu kepada anaknya yang lebih utama daripada mengajarkan adab yang baik.” (HR. al-Tirmiżî̀: 1952).

Hadits-hadits di atas jelas menerangkan tentang proses pengajaran yang berujung pada aplikasi (pengamalan), dan tidak sebatas aspek pengetahuan teoritis.

\section{Pemberian nasehat atau wejangan (al-Mau'izah).}

Wejangan (al-mau'izab) merupakan suatu bentuk pemberian nasehat (al-nașîhah) dan pengingatan (al-taخ̀îr) akan adanya akibat-akibat (al-'awâqib) ataupun risiko-risiko yang harus ditanggung di kemudian hari atas suatu perbuatan, baik itu adalah akibat baik (pahala) ataupun akibat buruk (dosa), hal ini dilakukan dengan tujuan melembutkan dan melunakkan hati (al-Hâzimî, 2015: 459).

Dari al-'Irbâḍ bin Sâriyah Radiliyallâhu 'Anhu berkata: Suatu hari Rasûlullâh Șalallâhu 'Alaihi Wa Sallam menasihati kami setelah șalat subuh, sebuah nasehat yang sangat mengena, membuat mata menangis dan hati bergetar. Ada seorang laki-laki yang berkata: Sesungguhnya ini adalah nasehat orang yang hendak berpisah, wahai Rasûlullâh, apa yang perintahkan kepada kami? beliau bersabda: "Aku wasiatkan kepada kalian untuk bertakwa kepada Allah, mendengar dan taat, meskipun (pemimpin kalian) adalah seorang budak Habasyah, karena sesungguhnya siapa dari kalian yang hidup sepeninggalku akan melihat perselisihan yang banyak. Jauhilah oleh kalian perkara-perkara baru dalam agama, karena sesungguhnya ia adalah kesesatan. Maka siapa dari kalian yang mengalami masa itu, hendaknya ia berpegang teguh dengan sunahku dan sunnah al-khulafâ alrâsyidîn al-mahdiyyîn, gigitlah ia dengan gigi-gigi geraham."(HR. al-Tirmiżî̀: 2676).

Nasehat yang baik (al-mau'izah al-hasanah) merupakan salah satu metode pendidikan dan dakwah yang utama, dalam rangka memberikan suatu pesan penting atau mengingatkan sesuatu untuk tidak dilupakan begitu saja, dan terkadang ditujukan kepada orang yang lalai dari suatu kewajiban (Al-Nadâwî: 344).

\section{Pemberian motivasi (al-Targîb).}

Al-Targî́b (motivasi) adalah semangat juang untuk menanggung suatu pekerjaan, atau berpegang pada suatu keyakinan, atau memberikan suatu gambaran yang fantastis, dan tidak ingin meninggalkannya (al-Ḥâzimî, 2015: 453).

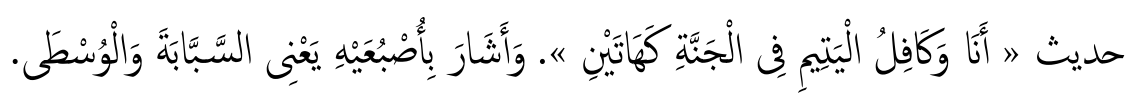

"Aku dan orang yang mengurus anak yatim berada di dalam surga seperti dua jari ini." Beliau mengisyaratkan dengan dua jarinya, yaitu jari telunjuk dan jari tengah. (HR. al-Tirmiziî: 19I8).

Motivasi yang diberikan dalam rangka pembinaan akhlak dan adab adalah motivasi ukhrawi, yakni mendapatkan suatu balasan yang jauh lebih baik dari apa yang dilakukan dan lebih kekal abadi.

\section{Pemberian ancaman (al-Tarhîb).}

Menurut al-Hâzimî (2015: 453), al-Tarbîb (ancaman) adalah tekanan terhadap suatu hal yang menakutkan karena meninggalkan sebuah pekerjaan, atau tidak berpegang pada suatu keyakinan yang benar, ataupun tidak memiliki gambaran yang pantas akan kebaikan. Hal ini 
dilakukan agar seseorang mencegah dirinya melakukan tindakan buruk ataupun tidak meninggalkan suatu kewajiban ataupun kebajikan.

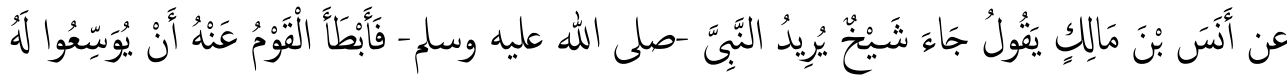

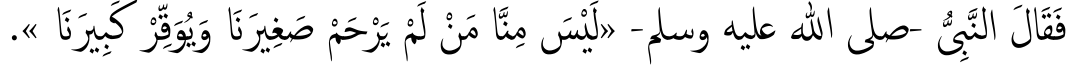

Dari Anas bin Mâlik Radiyallâhu 'Anhu, ia menceritakan: Ada seorang syeikh (orang tua) datang ingin bertemu dengan Nabi Șalallâhu 'Alaihi Wa Sallam, namun orang-orang yang menghalanginya dan tidak memberi tempat untuknya, maka Nabi Salallâhu 'Alaihi Wa Sallam bersabda: "Bukan termasuk golongan kami orang yang tidak menyayangi yang kecil dan menghormati yang tua." (HR. al-Tirmiżîi: 1919).

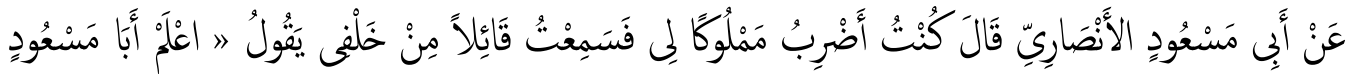

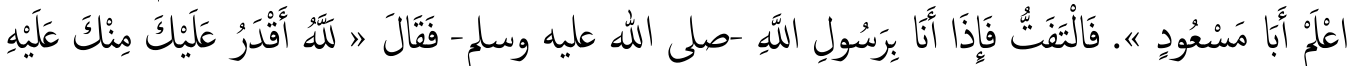

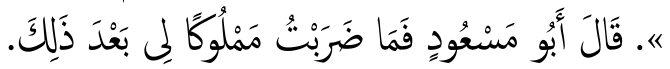

Dari Abu Mas'ûd al-Anșârî Raḍi iyallâhu 'Anhu berkata: Aku pernah memukul budakku, lalu aku mendengar seseorang berkata kepadaku: "Ketahuilah Abu Mas'ûd, ketahuilah Abu Mas 'ûd."Ketika aku menoleh kepadanya, ternyata adalah Rasûlullâh Saw, lalu beliau bersabda: "Allah lebih kuasa kepadamu ketimbang kamu kepadanya.” Kemudian Abu Mas'ûd Radiyallâhu 'Anhu berkata: Tidaklah aku memukul budakku setelah kejadian itu. (HR. al-Tirmiżî: 1948).

Hadîs-ḥadìs di atas menerangkan bahwa terkadang jiwa manusia lengah dan selalu menginginkan keburukan, diperlukan suatu perlakuan agar ia tunduk dan melunak. Salah satunya dengan pemberian ancaman akan dosa, siksa dan azab yang pedih, yang tidak dapat ditanggung (al-Ḥâzimî, 2015: 455-456).

\section{Pembiasaan (al-Ta'wîd).}

Metode pembiasaan merupakan cara yang paling efektif dalam menerapkan teori-teori keilmuan, agar tidak terasa berat saat mengerjakannya. Metode ini harus sering dilakukan berulang-ulang (al-tikrâr) dan terus menerus (al-dawâm), hingga suatu perbuatan menjadi jati diri dan karakteristiknya.

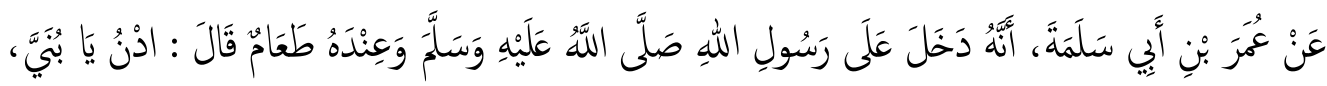

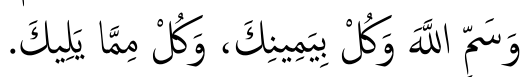

Dari 'Umar bin Abi Salamah Raḍiyallâhu 'Anhu bahwasanya ia menemui Rasûlullâh Șalallâhu 'Alaihi Wa Sallam yang sedang makan, beliau bersabda: "Mendekatlah wahai anakku, sebutlah nama Allâh, makanlah dengan tangan kananmu dan makanlah apa yang terdekat denganmu." (HR. al-Tirmiżî̀: 1857)

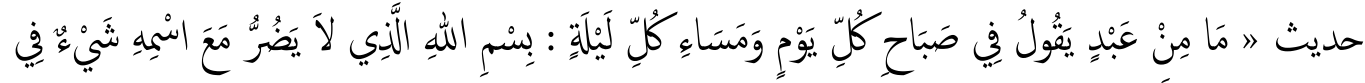

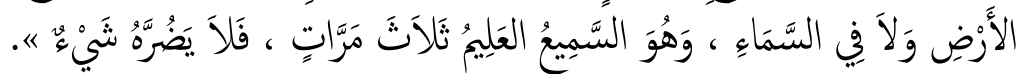

"Tidaklah seorang hamba membaca doa pada setiap pagi hari dan petang malam hari: Bismillâh allażî lâ yaḍurru ma'a ismihi syai' un fî al-arọi wa lâ fî al-samâ’ wa huwa Al-Samî Al-'Alîm, sebanyak tiga kali, maka tidak ada sesuatu pun yang menyakitinya.” (HR. al-Tirmiżî: 3388) 
Mendidik akhlak dan adab dilakukan semenjak usia dini, perlu ada pembiasaan dan dilakukan dengan terus menerus agar tertanam dalam jiwa, sehingga saat melakukannya tidak membutuhkan pemikiran dan penalaran lagi.

\section{Pemberian contoh yang baik (suri teladan) (al-Qudwah al-Hasanan).}

Menurut al-Hâzimî (2015: 439), salah satu sifat bawaan manusia sejak lahir adalah meniru atau mencontoh, baik perkataan ataupun perbuatan, yang baik ataupun yang buruk. Sehingga sangat penting untuk memberikan contoh-contoh yang baik atau suri teladan, terlebih lagi dalam aspek aplikatif. Karena jika sekedar ucapan semata, maka siapa pun dapat berbicara dengan berbagai dialektika dan retorika, akan tetapi siapa yang memberikan contoh aplikatif dari ucapannya. Ada ancaman yang besar terhadap sekedar ucapan kosong tanpa pengamalan (Qs. al-Ṣaff: 3)

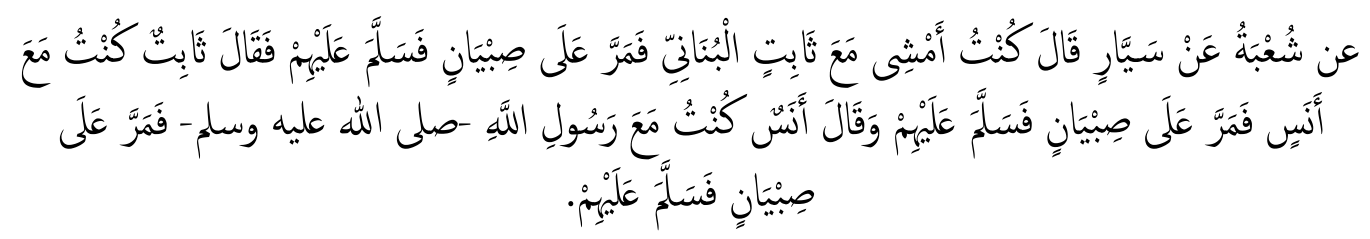

Dari Syu'bah dari Sayyâr, ia berkata: Aku pernah berjalan bersama Śabit al-Bunnâni, ia melewati beberapa anak kecil, lalu ia mengucapkan salam kepada mereka, Śabit berkata: Aku pernah berjalan bersama Anas, ia melewati beberapa anak, lalu ia mengucapkan salam kepada mereka, Anas Raḍiyallâhu 'Anhu berkata: Aku pernah berjalan bersama Rasûlullâh Șalallâhu 'Alaihi Wa Sallam, beliau melewati beberapa anak kecil, lalu beliau mengucapkan salam kepada mereka. (HR. alTirmiż̀î: 2696)

Rasulullah Șalallâhu 'Alaibi Wa Sallam sebagai uswah hasanah dalam ilmu dan amal, lahir dan batin, baik sebelum diangkat menjadi nabi dan rasul, maupun setelahnya, baik sebagai seorang individu, kepala rumah tangga, maupun sebagai kepala negara ('Athiyah, 2013: 115).

Pendidikan adab bukanlah sekedar tumpukan pengetahuan tanpa makna, akan tetapi yang jauh lebih penting dan fundamental adalah aspek pengamalan, bagaimana pengetahuanpengetahuan tersebut terwujud secara nyata dalam realitas kehidupan sehari-hari. Karena itu, diperlukan sosok role model yang patut dijadikan suri teladan sepanjang masa.

\section{Metode Dialog (al-Hiwâr).}

Manusia disebut juga sebagai hayawân națiq, dapat diartikan dengan makhluk yang berbicara. Sejatinya semua makhluk berbicara dengan bahasa-bahasa yang dipahami oleh komunitasnya. Hal itu dianugerahkan oleh Allah Subhânahu Wa Ta'ala untuk memenuhi semua kebutuhan-kebutuhan hidupnya, hingga terjadi dialog interaktif di antara mereka.

Menurut al-Nahlâwî (1999:206), metode dialog interaktif ini merupakan salah satu sarana transfer of knowledge yang cukup efektif, karena dapat menggugah dan menggerakkan daya pikir, nalar, logika serta perhatian peserta didik terhadap apa yang sedang terjadi.

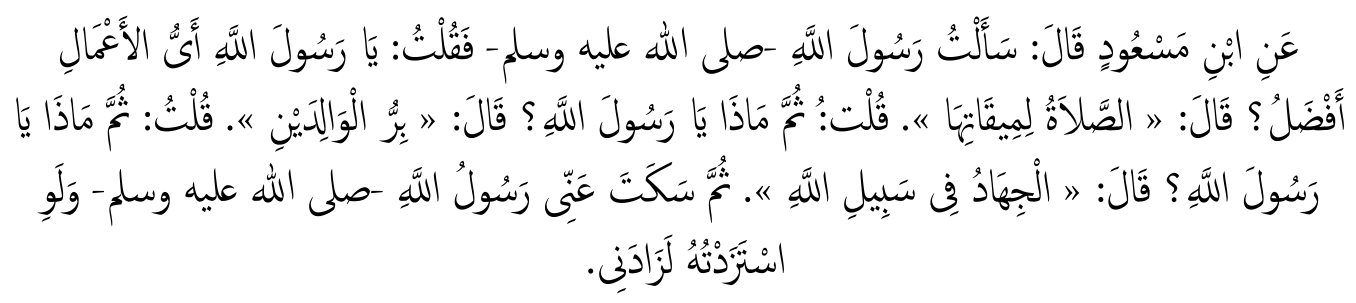

Dari Ibnu Mas'ûd Radiyallâhu 'Anhu berkata: Aku bertanya kepada Rasûlullâh Saw: Wahai Rasûlullâh, amalan apakah yang paling utama? Beliau Șalallâhu 'Alaihi Wa Sallam menjawab: 'Ṣalat pada waktunya." Kataku: Kemudian apa lagi wahai Rasûlullâh? Beliau bersabda: "Berbakti kepada 
kedua orang tua." Kataku lagi: Kemudian apa lagi wahai Rasûlullâh? Beliau bersabda: "Berjihad di jalan Allah.”Kemudian Rasûlullâh Șalallâhu 'Alaihi Wa Sallam menyuruhku untuk diam, sekiranya aku bertanya lagi maka beliau Șalallâhu 'Alaihi Wa Sallam pun akan menambahkan penyebutan lainnya. (HR. al-Tirmiżî: 1898).

Hadîs di atas menerangkan bahwa dialog yang terjadi antara Nabi Șalallâhu 'Alaibi Wa Sallam dengan sebagian dari sahabatnya sering kali terjadi dalam berbagai hal, keadaan, waktu, tempat, dan konteks yang beragam. Akan tetapi semua memiliki tujuan yang sama berupa pengajaran, pembimbingan, pengarahan, dan pemberian motivasi untuk lebih meraih kebahagiaan yang hakiki di dunia dan di akhirat dengan cara meningkatkan keimanan, ketakwaan dan amal șaleh (al-Nahlâwî, 1999:206).

\section{Memberikan perbandingan (al-Muqâranah)}

Ada suatu kaidah: al-diddu bi diddibi bayânu, artinya sesuatu yang disandingkan dengan lawannya akan menjadi lebih jelas. Metode al-muqâranah atau komparasi adalah cara membandingkan dua variabel atau lebih untuk mengetahui persamaan atau perbedaan darinya, aspek positif dan negatifnya (al-Nahlâwî, 1999:206).

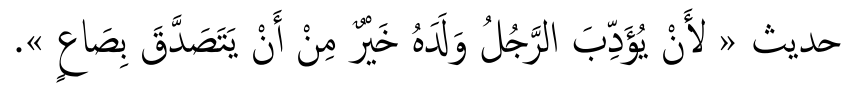

"Seseorang mendidik anaknya dengan adab yang baik itu lebih baik baginya dari bersedekah dengan satu sha'." (HR. al-Tirmiżîi: I95I).

Metode ini termasuk salah satu jenis pengajaran; memberikan perbandingan di antara dua hal yang berbeda, baik perbedaan dalam konteks kontradiksi, maupun dalam konteks keragaman untuk memilih yang terbaik salah satu dari keduanya. Terkadang seseorang membutuhkan sudut pandang yang berbeda dari apa yang dilihatnya sendiri, apalagi menyangkut keadaannya secara personal yang banyak orang tidak mengenalinya, kecuali dengan bantuan orang lain.

\section{Pemberian sanksi (hukuman) (al-Ta'dîb).}

Dalam pendidikan adab, pemberian sanksi hukuman bukan ditujukan untuk menghukum, menyakiti dan menyiksa. Akan tetapi memiliki maksud dan tujuan yang agung lagi mulia. Salah satunya adanya menegakkan prinsip keadilan, sekaligus kasih sayang. Kebaikan berbalas kebaikan yang berlipat ganda, sedangkan kejelekan mendapatkan balasan yang setimpal. Pemberian sanksi pun bertahap dan bertingkat-tingkat, disesuaikan dengan kebutuhan dan latar belakang yang berbeda-beda (al-Hâzimî, 2015:465).

Dari Sulaimân bin 'Amr al-Ahwaṣ, berkata: Bapakku menceritakan kepadaku bahwasanya ia ikut menunaikan Haji Wadâ' bersama Rasûlullâh Șalallâhu 'Alaihi Wa Sallam, beliau berkhotbah dengan memuja dan memuji Allah, menyanjung-Nya, lalu memberikan peringatan, menyampaikan nasehat, lalu dalam ḥadîṡnya disebutkan sebuah kisah, kemudian bersabda: "Ketahuilah, pergaulilah wanita dengan cara yang baik, sesungguhnya mereka adalah tawanan kalian, kalian tidak memiliki kuasa apa-apa atas mereka selain itu, kecuali mereka melakukan perbuatan keji yang sangat jelas, jika mereka berbuat demikian maka jauhkan mereka di tempat-tempat tidurnya, pukullah mereka dengan yang tidak menyakitkan, apabila mereka kembali menaati kalian maka janganlah mencaricari alasan menyakitinya, ketahuilah kalian memiliki hak atas istri-istri kalian, dan istri-istri kalian pun memiliki hak atas kalian, adapun hak kalian atas istri-istri kalian adalah tidak membiarkan orang yang kalian benci tidur di atas tempat tidur kalian dan tidak mengizinkan orang yang kalian benci masuk ke dalam rumah kalian, ketahuilah sedangkan hak mereka atas kalian adalah kalian memberikan pakaian dan makanan yang terbaik untuk mereka." (HR. al-Tirmizî̀: II63).

Ḥadî́ ini sejatinya menguatkan firman Allah dalam al-Qur'an di surat al-Nisâ' ayat 34 tentang tahapan pembinaan (al-ta'dîb) atas seorang istri yang melakukan nusy $\hat{u} z$, terhadap 
suaminya, dimulai dari pemberian nasehat yang menerangkan tentang hak-hak dan kewajiban-kewajiban suami istri. Jika belum ada perbaikan, maka melangkah ke tahap selanjutnya, yaitu pisah ranjang. Apabila masih tidak ada perubahan sikap menjadi lebih baik, seorang suami dibolehkan untuk mengambil langkah berikutnya, yaitu memukul dengan pukulan yang tidak membahayakan dan tidak mencelakakan, serta tidak ditujukan untuk memukul wajah. Jikalau belum ada perubahan sikap ke arah yang lebih baik, maka dilakukan upaya perdamaian ke dua belah pihak dengan cara perundingan para kuasa hukum dari keduanya (Qs. al-Nisâ': 35). Barulah setelah berlalu semua itu, maka seorang suami menjatuhkan țalaq (cerai) kepada isterinya secara bertahap, yaitu țalaq satu, kemudian țalaq dua, terakhir țalaq tiga (țalaq bầin) (Qs. al-Baqarah: 229).

\section{Menyampaikan kisah (Ta'bîr al-Qașaș).}

Kisah umat-umat terdahulu yang tercantum dalam al-Qur'an mengandung pelajaranpelajaran yang sangat berharga, bahwa setiap kebaikan akan menghasilkan buah yang baik, sedangkan setiap kejelekan pun akan berbalas dengan kejelekan dan kecelakaan hingga sampai pada kebinasaan (Qs. Yusuf: 111).

Dalam pendidikan adab, materi kisah yang disampaikan sudah barang tentu memuat sederetan nilai-nilai kebajikan, dan karakter-karakter baik lainnya, seperti perjuangan, pengorbanan, ketulusan, solidaritas, dan sebagainya. Namun demikian tidak setiap kisah dapat diceritakan, akan tetapi kisah yang dilandasi oleh kebenaran dan kejujuran. Metode ini sering digunakan dalam pendidikan anak, karena secara naluri usia anak menyukai hal-hal yang imaginatif dalam daya pikir dan nalar mereka, karenanya diperlukan cara yang tepat dalam menyampaikan kisah kepada mereka.

Dari Abu Hurairah Raḍiyallâhu 'Anhu dari Nabi Șalallâhu 'Alaihi Wa Sallam bersabda: "Ketika seseorang sedang berjalan di suatu jalan tiba-tiba ia dapati ranting berduri, lalu disingkirkannya, maka Allah berterima kasih kepadanya kemudian mengampuninya.” (HR. al-Tirmiżî̀: 1958).

\section{E. Evaluasi Pendidikan Adab}

Evaluasi pendidikan adab juga dapat berupa pemberian sanksi (hukuman) secara bertahap, biasa disebut dengan al-ta'dîb (pembinaan adab) agar seorang muslim menyadari kekeliruannya, untuk kemudian ia memperbaikinya. Sebagaimana ditunjukkan dalam ḥadî̀ berikut:

Dari Sulaimân bin 'Amr al-Ahwaș, berkata: Bapakku menceritakan kepadaku bahwasanya ia ikut menunaikan Haji Wadâ’ bersama Rasûlullâh Șalallâhu 'Alaihi Wa Sallam, beliau berkhotbah dengan memuja dan memuji Allah, menyanjung- $\mathrm{Nya}$, lalu memberikan peringatan, menyampaikan nasehat, lalu dalam ḥadîṡnya disebutkan sebuah kisah, kemudian bersabda: "Ketahuilah, pergaulilah wanita dengan cara yang baik, sesungguhnya mereka adalah tawanan kalian, kalian tidak memiliki kuasa apa-apa atas mereka selain itu, kecuali mereka melakukan perbuatan keji yang sangat jelas, jika mereka berbuat demikian maka jauhkan mereka di tempat-tempat tidurnya, pukullah mereka dengan yang tidak menyakitkan, apabila mereka kembali menaati kalian maka janganlah mencaricari alasan menyakitinya, ketahuilah kalian memiliki hak atas istri-istri kalian, dan istri-istri kalian pun memiliki hak atas kalian, adapun hak kalian atas istri-istri kalian adalah tidak membiarkan orang yang kalian benci tidur di atas tempat tidur kalian dan tidak mengizinkan orang yang kalian benci masuk ke dalam rumah kalian, ketahuilah sedangkan hak mereka atas kalian adalah kalian memberikan pakaian dan makanan yang terbaik untuk mereka." (HR. al-Tirmiżîi: II63).

Evaluasi pendidikan adab juga dapat berupa teguran, baik secara langsung maupun sindiran, guna meluruskan persepsi yang keliru, kurang tepat, selanjutnya dapat mengakibatkan aplikasi perbuatan yang tidak sesuai dengan petunjuk syariat agama Islam. Sebagaimana ditunjukkan dalam ḥadîs berikut: 
Dari 'Urwah bahwa 'Âisyah Radiyallâhu 'Anha menceritakan kepadanya: Bahwasanya Barîrah datang meminta tolong kepada 'Âisyah Radiiyallâhu 'Anha dalam hal pembebasan dirinya, sedangkan ia belum pernah membayar sesuatu pun untuk pembebasannya, maka 'Âisyah Radiyallâhu 'Anha berkata kepadanya: Pulanglah kamu ke keluargamu, jika mereka ingin aku yang memerdekakanmu dan walâ-mu menjadi milikku maka akan aku lakukan. Kemudian Barîrah menceritakan hal itu kepada keluarganya, namun mereka enggan. Mereka berkata: Jika ia ('Âisyah Radivallâhu 'Anha) mau untuk mengambil upah atas pembebasanmu, namun walâ'-mu tetap milik kami, silakan lakukan. Lalu ia ('Âisyah Radiyallâhu 'Anha) menceritakan hal itu kepada Rasûlullâh Salallâhu 'Alaihi Wa Sallam, maka Rasûlullâh Salallâhu 'Alaihi Wa Sallam bersabda: "Belilah dia, lalu merdekakan dia, karena hanyalah walầ itu milik orang yang memerdekakan." Kemudian Rasûlullâh Șalallâhu 'Alaihi Wa Sallam bersabda: "Bagaimana suatu kaum mempersyaratkan syaratsyarat yang tidak terdapat dalam Kitâbullâh?! Siapa yang menetapkan satu syarat yang tidak terdapat dalam Kitâbullâh, maka ia tidak mendapatkan apa-apa, meskipun seratus syarat."(HR. al-Tirmiżî: 2124).

Dari penjelasan di atas, dapat disimpulkan bahwa evaluasi pendidikan adab dapat dilakukan dengan teknik pengamatan langsung (al-MulâhaZạb), pembinaan adab (al-Ta'dîb), dan teguran atau pengingatan ( $a l-T a \dot{z} k \hat{i} r)$.

\section{Relevansinya Dengan Tujuan Pendidikan Nasional}

Berbagai aturan perundang-undangan yang disusun oleh Pemerintah untuk tata laksana dan tata kelola pendidikan adalah menitik beratkan pada pendidikan karakter. Dalam Undang-Undang No. 20 tahun 2003 tentang Sistem Pendidikan Nasional disebutkan bahwa pendidikan adalah usaha sadar dan terencana untuk mewujudkan suasana belajar dan proses pembelajaran agar peserta didik secara aktif mengembangkan potensi dirinya untuk memiliki kekuatan spiritual keagamaan, pengendalian diri, kepribadian, kecerdasan, akhlak mulia, serta keterampilan yang diperlukan dirinya, masyarakat, bangsa dan negara.

Lebih jelas lagi akan fungsi dan tujuan pendidikan nasional dirumuskan dalam UU SISDIKNAS di atas, bahwa pendidikan nasional berfungsi mengembangkan kemampuan dan membentuk watak serta peradaban bangsa yang bermartabat dalam rangka mencerdaskan kehidupan bangsa, bertujuan untuk berkembangnya potensi peserta didik agar menjadi: a) manusia yang beriman dan bertakwa kepada Tuhan Yang Maha Esa, b) berakhlak mulia, c) sehat, d) berilmu, e) cakap, f) kreatif, g) mandiri, dan h) menjadi warga negara yang demokratis serta bertanggung jawab.

Konsep pendidikan adab dalam kitab al-Jâmi' al-Saḩị̂ karya Imam al-Tirmiżî memiliki relevansi yang sangat baik terhadap tujuan pendidikan nasional, dan dapat dijadikan sebagai bahan pengayaan dan pengembangan kurikulum Pendidikan Nasional dengan penekanan pada nilai-nilai keimanan (baca: Taubîdullâh) sebagai dasar yang melandasi segenap sistematika kurikulum pendidikan akhlak dan adab.

Dengan kata lain al-Âdâb as core of education sebagai manifestasi dari tauhid seorang hamba kepada Allah Subhânahu Wa Ta'ala. Tahapan proses al-Ta'dîb tersebut harus mengenai seluruh dimensi manusia (agama, jiwa, akal, kehormatan dan harta) dan dilakukan secara terus menerus berkesinambungan, melalui metode-metode yang efektif, seperti metode pembiasaan

\section{Penutup}

Perbaikan karakter anak bangsa merupakan tanggung jawab bersama, antara pemerintah, masyarakat dan lembaga-lembaga pendidikan, termasuk instansi-instansi lainnya. Keberhasilan pendidikan karakter juga ditentukan oleh adanya komitmen bersama antara seluruh komponen bangsa di seluruh aspek kehidupan berbangsa dan bernegara. 
Konsep pendidikan adab dalam kitab al-Jâmi' al-Ṣaḩ̧̣̂ karya Imam al-Tirmizî̀ dapat dijadikan sebagai salah satu bahan referensi dan pengayaan dalam merumuskan struktur kurikulum pendidikan nasional, karena muatan dan kandungannya yang cukup lengkap dan menyeluruh meliputi pendidikan potensi-potensi dasar manusia (hati, akal, rasa, karsa dan raga) dalam tiga relasi secara horizontal dan vertikal; interaksi manusia dengan Tuhannya, dengan dirinya sendiri dan dengan lingkungannya.

\section{Daftar Pustaka}

'Ațiyah, 'I. bin M. bin M. (2013). al-Tarbiyah al-Islâmiyah: Mașâdirubâ wa Tațbîqâtuhâ, Kairo: Maktabah al-Rusyd.

al-Abbad, A. A. M. (2018). Syarh Sunan Abi Dawud, Maktabah Syamilah.

Al-Haitâmî, A. bin M. bin 'A. bin H. A. A. 'A. S. A. D. A. H. (2008). al-Fath al-Mubinn Syarh alArba'în, Jeddah: Dâr al-Minhaj.

Al-Ḥ̂zimî, K. bin H.. bin M., (2015). Ușûl al-Tarbiyah al-Islâmiyah, Madinah: Maktabah Dâr alZamân.

al-Katîrî, Ṭ bin 'U. Maqâlah Hadîs: wa khâliq al-nâs bi khuluqin hasan. Dinukil dari website: https://www.alukah.net/sharia/0/105308/\#ixzz6A803zmKM.

Al-Mubârakfuri, M. A. bin A. A. A. 'U. (2005), Tuhfah al-Ahważi, Kairo: Dâr al-Hadîśs.

Al-Munâwî, M. bin T. A. Â. bin 'A. Z. A. D. A. M. (1994). Faị̣ al-Qadîr Syarh al-Jâmi al-Sagîr, Beirut: Dâr al-Kutub al-Ilmiyah.

Al-Nadawî, M. U. (tt). Tafsîr al-Qayyim Lî Ibni al-Qayyim, Beirut: Maktabh al-Kutub al-'Tlmiah. Al-Nahlâwî, 'A. (1999). Ușûl al-Tarbiyah al-Islâmiyah, Beirut: Dâr al-Fikr.

Ma’arif, S. (2007). Revitalisasi Pendidikan Islam, Yogyakarta: Graha Ilmu.

Mannâ', A. Q. (2000). Mabâbis̉ fì 'Ulûm al-Qur'ân, Kairo: Maktabah al-Ma'ârif.

Purnomo, S. (2014). Pendidikan Karakter Di Indonesia: Antara Asa Dan Realita. Jurnal Kependidikan, 2(2), 66-84. doi: 10.24090/jk.v2i2.553

Pusat Analisis Dan Sinkronisasi Kebijakan Sekjen Kemendikbud (PASK Kemen-dikbud), 2017, Penguatan Pendidikan Karakter (PPK)-Modul Pelatihan Bagi Pengawas, Jakarta: Kemendikbud.

Setyawan, D. (2017, December 18). KPAI: Ada 3849 Pengaduan Kasus Anak pada Tabun 2017. Retrieved May 6, 2021, from Komisi Perlindungan Anak Indonesia (KPAI) website: https://www.kpai.go.id/publikasi/kpai-ada-3849-pengaduan-kasus-anak-pada-tahun-2017

Wijaya, L. D. (2018). Kasus Korupsi Tahun 2017, ICW: Kerugian Negara Rp 6,5 TriliunNasional Tempo.co. Retrieved from https://nasional.tempo.co/read/1062534/kasuskorupsi-tahun-2017-icw-kerugian-negara-rp-65-triliun 